\title{
Electrochemical Deposition of Mn:ZnO Films under Hydrothermal Conditions
}

\author{
Ceren Yilmaz ${ }^{\mathrm{a}}$ and Ugur Unal ${ }^{\mathrm{a}, \mathbf{b}, \mathbf{c}, *, \mathbf{z}}$ \\ ${ }^{a}$ Graduate School of Science and Engineering, Koc University, Sariyer 34450, Istanbul, Turkey \\ ${ }^{b}$ Koc University, Chemistry Department, Sariyer, 34450 Istanbul, Turkey \\ ${ }^{c}$ Koc University Surface Science and Technology Center (KUYTAM), Sariyer, 34450 Istanbul, Turkey
}

\begin{abstract}
This study demonstrated the electrochemical deposition of $\mathrm{Mn}$-doped $\mathrm{ZnO}$ films under hydrothermal conditions at $130{ }^{\circ} \mathrm{C}$ in $50 \% \mathrm{v} / \mathrm{v}$ DMSO- $\mathrm{H}_{2} \mathrm{O}$ mixture. X-ray diffraction analysis showed that the deposition of the $\mathrm{ZnO}$ structures was along (002) direction. However, the presence of $\mathrm{Mn}^{2+}$ affected the thickness of $\mathrm{ZnO}$ structures and we believe that the interaction of Mn ${ }^{2+}$ with the nonpolar surface of $\mathrm{ZnO}$ restricts lateral growth. Mn appears in the mixed oxide state in $\mathrm{ZnO}$ lattice. The photoluminescence spectra of the films show only UV emission indicating high crystal quality. The blueshift of the UV emission is observed after the introduction of Mn impurity into the $\mathrm{ZnO}$ lattice. The surface morphology, lattice structure, Mn content, chemical binding characteristics, and optical properties of the deposits were examined by scanning electron microscopy, X-ray diffraction, X-ray photoelectron spectroscopy and photoluminescence spectroscopy, respectively.

(C) 2013 The Electrochemical Society. [DOI: 10.1149/2.077304jes] All rights reserved.
\end{abstract}

Manuscript submitted November 20, 2012; revised manuscript received February 7, 2013. Published February 18, 2013.

Over the past few decades, $\mathrm{ZnO}$ has regained its importance among numerous groups especially in the materials research and device fabrication technologies. $\mathrm{ZnO}$ is an n-type semiconductor with a wide bandgap $(3.37 \mathrm{eV})^{1}$ and large exciton binding energy $(60 \mathrm{meV})^{2}$ in hexagonal wurtzite crystal structure. It is shown to be a very promising material in a wide range of application areas from sensors ${ }^{3}$ to optoelectronic devices such as lasers, ${ }^{4,5}$ optical switches, ${ }^{6}$ light emitting diodes, ${ }^{7}$ phototransistors ${ }^{8}$ and solar cells. ${ }^{9}$ It is possible to modify electrical and optical properties of $\mathrm{ZnO}$ to broaden possible applications in ultraviolet optoelectronics ${ }^{10}$ and spin electronics ${ }^{11}$ through impurity incorporation. To tune these properties which are very sensitive to the shape of the particles and the preparation method, considerable attention has been paid to metal doping; a few examples are $\mathrm{Mn}^{2+}$, $\mathrm{Cu}^{2+}, \mathrm{Cd}^{2+}, \mathrm{Co}^{2+}, \mathrm{Ni}^{2+}, \mathrm{Mg}^{2+}$ and $\mathrm{Fe}^{2+} \cdot{ }^{10-12}$ Although the origin of ferromagnetism in transition- metal doped $\mathrm{ZnO}$ is not yet very clearly understood and highly debatable, ${ }^{13}$ there is an increasing interest to study $\mathrm{ZnO}$ as a ferromagnetic material candidate. ${ }^{14,15}$ Among these materials, Mn-doped $\mathrm{ZnO}$ crystals receive growing attention as diluted magnetic semiconductor materials (DMS) for spintronics. ${ }^{16,17}$ Furthermore, modifying optical properties of $\mathrm{ZnO}$ through engineering the bandgap with Mn doping is also of interest to many groups. ${ }^{14,18,19}$

Several methodologies were employed to obtain Mn-doped $\mathrm{ZnO}$ particles including spray pyrolysis ${ }^{19}$ chemical vapor deposition, ${ }^{11}$ magnetron sputtering, ${ }^{20}$ sol-gel process, ${ }^{21}$ pulsed laser deposition ${ }^{18}$ and electrodeposition. ${ }^{17}$ The first few techniques require high temperatures. Moreover, vapor-based techniques involve introduction of catalysts that might affect the physical properties of the product. Electrochemical synthesis, on the other hand, has emerged as a simpler alternative to produce semiconductor nanostructures. It is a cost effective method where large area thin films on various substrates of arbitrary shapes can be produced at lower temperatures while control over growth rate, film thickness and morphology are maintained. However, there are no reports on synthesis of Mn-doped $\mathrm{ZnO}$ by a combination of hydrothermal techniques and electrochemistry which allows electrodeposition at higher temperatures than it is possible with air-open systems. In this present study, we report seedless electrochemical growth of Mn-doped $\mathrm{ZnO}$ films with this combined hydrothermalelectrochemical method for the first time and the effect of manganese ion amount on the morphology and physical properties of $\mathrm{ZnO}$ films were characterized.

\section{Experimental}

Materials.- All the chemicals used were of analytical grade or of the highest purity commercially available. Manganese chloride

${ }^{*}$ Electrochemical Society Active Member.

${ }^{\mathrm{z}}$ E-mail: ugunal@ku.edu.tr tetrahydrate $\left(\mathrm{MnCl}_{2} \cdot 4 \mathrm{H}_{2} \mathrm{O}\right)$ was obtained from Merck and zinc nitrate hexahydrate $\left(\mathrm{Zn}\left(\mathrm{NO}_{3}\right)_{2} \cdot 6 \mathrm{H}_{2} \mathrm{O}\right)$ was purchased from Sigma-Aldrich. Dimethyl sulfoxide (DMSO) was supplied from Alfa Aesar. Indium Tin Oxide (ITO) $\left(\Omega<5.0 \times 10^{-4}\right.$ ohm.cm $)$ was purchased from Teknoma Ltd. Izmir, Turkey. Double distilled, high purity water was used from Milli-Q water (Millipore) system.

Electrochemical synthesis of $\mathrm{ZnO}$ films. - Doped $\mathrm{ZnO}$ layers were grown on ITO-coated glass electrode $\left(1 \times 1 \mathrm{~cm}^{2}\right.$ area $)$ in DMSO, water and 1:1 DMSO/water mixture. $\mathrm{MnCl}_{2}$ was used as dopant metal source and baths with fixed $\left(\mathrm{Zn}\left(\mathrm{NO}_{3}\right)_{2}\right.$ concentration $(50 \mathrm{mM})$ and different $\left[\mathrm{Mn}^{2+}\right]$ to $\left[\mathrm{Zn}^{2+}\right]$ ratios were prepared. Electrodepositions were carried out with a conventional 3 electrode cell system in a hydrothermal glass reactor (Büchiglasuster, picoclave) at constant potential. The reference electrode was $\mathrm{Ag} / \mathrm{AgCl}$ saturated with $\mathrm{KCl}$ (Corr Instruments, S/N P11092) whereas Pt wire served as counter electrode. The substrate was cleaned ultrasonically by ethanol,acetone and distilled water prior to depositions. The growth temperature was $130^{\circ} \mathrm{C}$. The potentiometric deposition was performed at $-1.1 \mathrm{~V}$ vs $\mathrm{Ag} / \mathrm{AgCl}$ reference electrode with a potensiostat/galvanostat (VSP, Biologic-Science Instruments).

Characterization.- The crystal structure and crystallinity of the samples were analyzed by X-ray Diffraction (XRD) analysis using Bruker/D8 Advance with $\mathrm{Cu} \mathrm{K} \alpha$ radiation. The surface morphology of the films was examined with ZEISS Ultraplus Field Emission Scanning Electron Microscope (FE-SEM). The film composition was studied by X-Ray photoelectron spectroscopy (XPS, Thermo K-Alpha). The binding energies were calibrated by taking $\mathrm{C} 1 \mathrm{~s}(285 \mathrm{eV})$ as reference. The $\mathrm{Mn}$ content relative to $\mathrm{Zn}$ was calculated by differentiating the area under the $\mathrm{Zn} 2 \mathrm{p}_{3 / 2}$ and $\mathrm{Mn} 2 \mathrm{p}_{3 / 2}$ curves. Photoluminescence spectra of the films were recorded by Horiba Jobin Yvon-Fluoromax 3 spectrofluorometer between $375-700 \mathrm{~nm}$ at $355 \mathrm{~nm}$ excitation wavelength.

\section{Results and Discussion}

We have investigated the affect of $\mathrm{Mn}^{2+}$ on the morphology of $\mathrm{ZnO}$ films with an electron microscope. Figure 1a shows SEM image of the $\mathrm{ZnO}$ film prepared from $50 \mathrm{mM} \mathrm{Zn}\left(\mathrm{NO}_{3}\right)_{2}$ in DMSO: $\mathrm{H}_{2} \mathrm{O}$ mixture. For this undoped $\mathrm{ZnO}$ film, formation of thick platelets with edges on the order of about 1-2 $\mu \mathrm{m}$ was observed. Rest of the Figure 1 displays as-prepared (Mn)-doped $\mathrm{ZnO}$ films deposited from baths with different $\mathrm{Mn}$ (II): $\mathrm{Zn}$ (II) feed ratios. Addition of $\mathrm{Mn}$ (II) into the electrodeposition bath also gave rise to platelets that were grown into each other with smaller sized edges which were ranging between 1.3 and $1.5 \mu \mathrm{m}$. When $\mathrm{Mn}$ (II) concentration was increased, fairly 

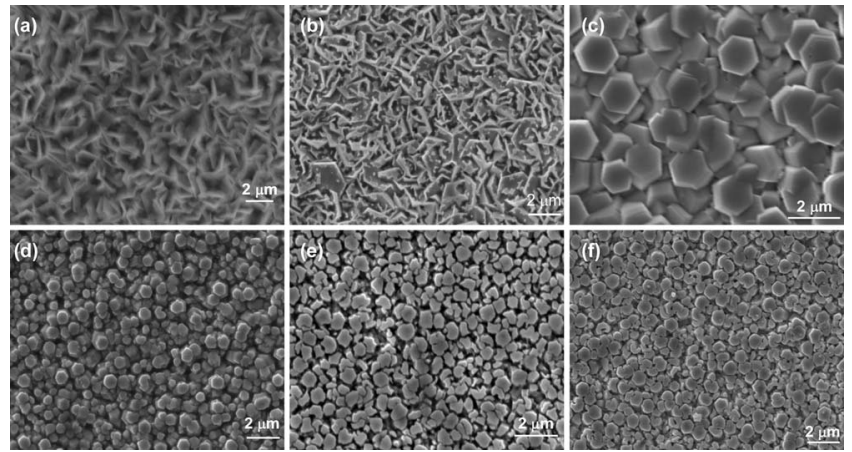

Figure 1. FE-SEM images of films prepared from baths with different feed ratios. a) only $\mathrm{Zn}\left(\mathrm{NO}_{3}\right)_{2}$ b) $\left.[\mathrm{Mn}(\mathrm{II})] /[\mathrm{Zn}(\mathrm{II})]=0.2 \mathrm{c}\right)[\mathrm{Mn}(\mathrm{II})] /[\mathrm{Zn}(\mathrm{II})]=0.4$ d) $[\mathrm{Mn}(\mathrm{II})] /[\mathrm{Zn}(\mathrm{II})]=0.6 \mathrm{e})[\mathrm{Mn}(\mathrm{II})] /[\mathrm{Zn}(\mathrm{II})]=0.8 \mathrm{f})[\mathrm{Mn}(\mathrm{II})] /[\mathrm{Zn}(\mathrm{II})]=1$.

uniform, well-aligned hexagonal rods strongly oriented toward the $c$ axis were observed. Crystals smaller in the (0001) faces were grown along $<0001>$ direction with hexagonal caps. Further addition of $\mathrm{Mn}$ (II) into the mixture induced further reduction in the width-tolength ratio of the particles without triggering any change in the morphological characteristics of the crystals. Diameters of the hexagonal rods decreased gradually from about $1.7-1.4 \mu \mathrm{m}$ to $0.7 \mu \mathrm{m}$ with increasing Mn(II) concentration. On the other hand, increase in Mn(II) concentration does not affect the thickness of the films as seen in Figure 2.

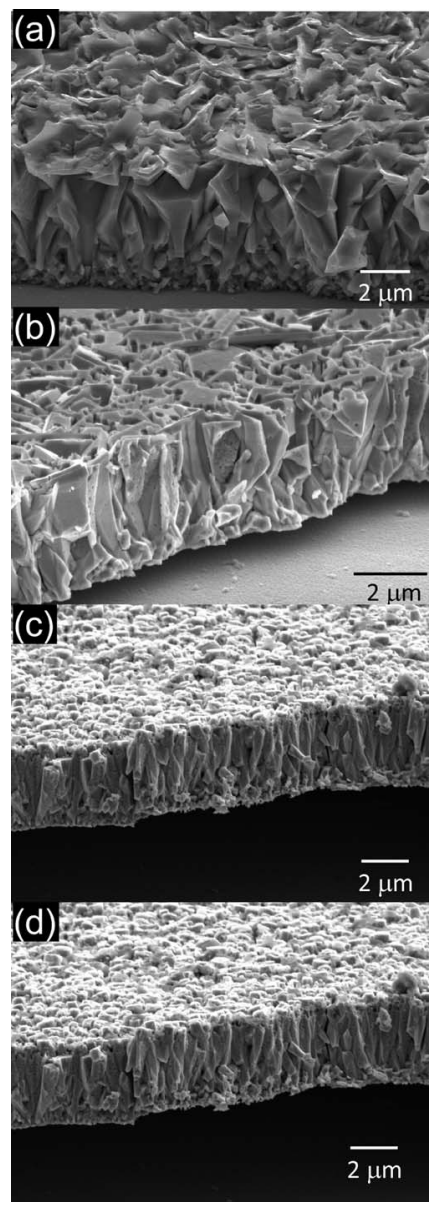

Figure 2. Cross-sectional FE-SEM images of the films prepared with different feed ratios. a) Only $\mathrm{Zn}\left(\mathrm{NO}_{3}\right)_{2}$, b) $\left.[\mathrm{Mn}(\mathrm{II})] /[\mathrm{Zn}(\mathrm{II})]=0.2 \mathrm{c}\right)[\mathrm{Mn}(\mathrm{II})] /[\mathrm{Zn}(\mathrm{II})]$ $=0.6 \mathrm{~d})[\mathrm{Mn}(\mathrm{II})] /[\mathrm{Zn}(\mathrm{II})]=1$.

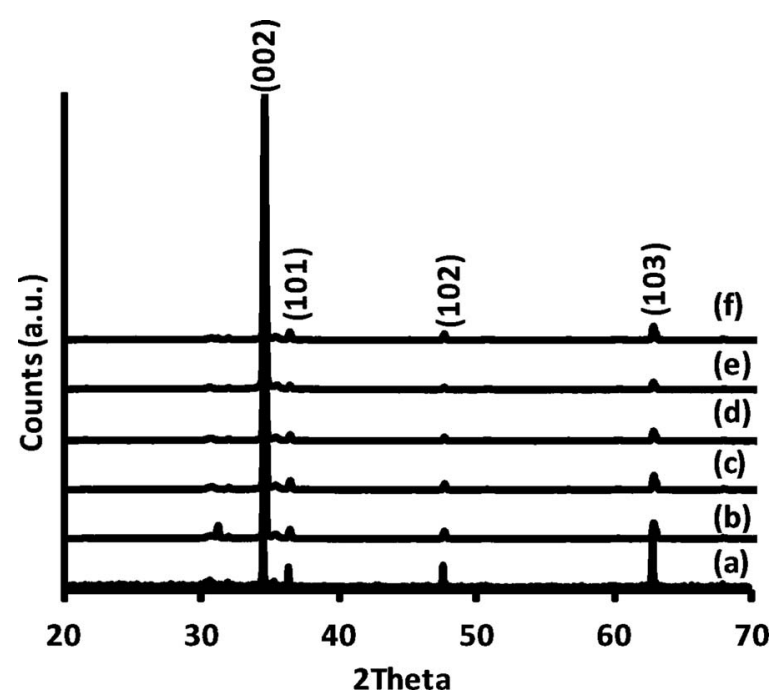

Figure 3. XRD patterns of films prepared from baths with different feed ratios. a) only $\mathrm{Zn}\left(\mathrm{NO}_{3}\right)_{2}$ b) $\left.[\mathrm{Mn}(\mathrm{II})] /[\mathrm{Zn}(\mathrm{II})]=0.2 \mathrm{c}\right)[\mathrm{Mn}(\mathrm{II})] /[\mathrm{Zn}(\mathrm{II})]=0.4$ d) $[\mathrm{Mn}(\mathrm{II})] /[\mathrm{Zn}(\mathrm{II})]=0.6 \mathrm{e})[\mathrm{Mn}(\mathrm{II})] /[\mathrm{Zn}(\mathrm{II})]=0.8 \mathrm{f})[\mathrm{Mn}(\mathrm{II})] /[\mathrm{Zn}(\mathrm{II})]=1$.

The structure of the transition metal doped $\mathrm{ZnO}$ films were characterized by X-ray diffraction. For the sample prepared in the absence of $\mathrm{Mn}^{2+}$, XRD pattern revealed typical three peaks which can be indexed to (100), (002) and (101) reflections of hexagonal wurtzite $\mathrm{ZnO}$ structure (JCDPDS No. 0361451) without any other phase being detected (Figure 3), although (002) peak is highly intensified. The strong (002) peak observed in all of the samples indicated highly crystalline, well aligned doped $\mathrm{ZnO}$ particles that were preferentially grown vertically to the substrate in line with SEM images. The intensity ratio of (002) reflection to (100) reflection was 14 for the film prepared in the absence of $\mathrm{Mn}^{2+}$. For all other $\mathrm{Mn}$-doped $\mathrm{ZnO}$ films the same ratio was around 100. Regardless of the concentration of $\mathrm{Mn}$ (II) ions, no shift in the position of (002) peak hence in the lattice parameters was observed. It can be attributed either to similar radii of the two cations $^{22}$ (where $\mathrm{Mn}^{2+}$ ionic radius is $0.66 \AA$ and those of $\mathrm{Zn}^{2+}$ ionic radius is $0.60 \AA^{12}$ ) or to low doping level of manganese ions. It is already established for $\mathrm{Cd}$-doped $\mathrm{ZnO}$ films that doping levels lower than $9 \%$ does not induce a change in the lattice parameters. ${ }^{23}$

Surfactants or capping agents are commonly used to modify the morphology of the particles through passivation of one or more faces selectively at the expense of the others in the colloid science. We believe capping ability of $\mathrm{Mn}(\mathrm{II})$ ions together with the high temperature are the key actors in the formation of the obtained structures. Electrodeposition from nitrate precursors is driven by the reduction of nitrate. ${ }^{24}$ Reduction of nitrate ions coming from the dissolution of $\mathrm{Zn}\left(\mathrm{NO}_{3}\right)$ precursors (Eq. 1) to nitrite ions gives rise to increase in $\mathrm{pH}$ through formation of $\mathrm{OH}^{-}$ions (Eq. 2). The hydroxide ions in turn, cause precipitation of zinc hydroxide (Eq. 3; hydroxylation) at the cathode. Zinc hydroxide is then dehydrated to generate $\mathrm{ZnO}$ (Eq. 4; dehydration).

$$
\begin{gathered}
\mathrm{Zn}\left(\mathrm{NO}_{3}\right)_{2} \rightarrow \mathrm{Zn}^{2+}+2 \mathrm{NO}_{3}^{-} \\
\mathrm{NO}_{3}^{-}+\mathrm{H}_{2} \mathrm{O}+2 \mathrm{e}^{-} \rightarrow \mathrm{NO}_{2}^{-}+2 \mathrm{OH}^{-} \\
\mathrm{Zn}^{2+}+2 \mathrm{OH}^{-} \rightarrow \mathrm{Zn}(\mathrm{OH})_{2} \\
\mathrm{Zn}(\mathrm{OH})_{2} \rightarrow \mathrm{ZnO}+\mathrm{H}_{2} \mathrm{O}
\end{gathered}
$$

Tetrahedrally coordinated $\mathrm{O}^{2-}$ and $\mathrm{Zn}^{2+}$ ions stacked alternatively along the $c$ axis make up the wurtzite crystal structure. ${ }^{25}$ Due to this arrangement of atoms, $\mathrm{ZnO}$ posses a negatively charged, basal 
O-(0001) polar plane and a positively charged $\mathrm{Zn}-(0001)$ plane. In addition, $\mathrm{ZnO}$ crystal growth rate was shown to be five times faster on the $\{0001\}$ planes than it is on the $\{1010\}$ and $\{0110\}$ planes ${ }^{26}$ which would yield particles with a relatively high aspect ratio. Despite of this preferential growth direction it is possible to obtain 2-D $\mathrm{ZnO}$ structures in the presence of $\mathrm{KCl}$ from highly concentrated $\mathrm{Zn}\left(\mathrm{NO}_{3}\right)_{2}$ baths $(100 \mathrm{mM}, 50 \mathrm{mM}) \cdot{ }^{27,28}$ It is suggested that selective adsorption of $\mathrm{Cl}^{-}$ions on the polar (0001) plane is responsible for the redirected growth on the nonpolar (1010) plane. However, Pradhan and Leung observed an opposite behavior with dilute $\mathrm{Zn}\left(\mathrm{NO}_{3}\right)_{2}$ solutions. ${ }^{28}$ They explained the contradictive behavior at low $\mathrm{Zn}\left(\mathrm{NO}_{3}\right)_{2}$ electrolyte concentrations with hydroxylation kinetics. It is suggested that slower hydroxylation reaction (formation of $\mathrm{Zn}(\mathrm{OH})_{2}$ ) at low electrolyte concentrations provides time for desorption of $\mathrm{Cl}^{-}$ions from the polar surface. Since the hydroxylation reaction is slower, as soon as zinc hydroxide is formed, it is converted to zinc oxide leading to the formation of 1-D materials. In hydrothermal-electrochemical synthesis we observed preferential growth along (0001) plane perpendicular to the substrate even at high electrolyte concentrations with or without $\mathrm{KCl}(100 \mathrm{Mm} \mathrm{Zn}, 100 \mathrm{Mm} \mathrm{KCl})$. We believe this concentration independent morphology can be explained by the combined effect of desorption of $\mathrm{Cl}^{-}$at low concentrations and the increased rate of dehydration reaction at even higher temperature and pressure. The dehydration reaction, conversion of the initially formed zinc hydroxide to zinc oxide, is already shown to be increasing with deposition temperature noticeably. ${ }^{29}$ Development of zinc oxide seed crystals might be even faster at $130^{\circ} \mathrm{C}$. Since $\mathrm{Cl}^{-}$ions does not alter the morphology of the crystals, $\mathrm{Mn}$ (II) ions are responsible for the transformation from coalesced hexagonal platelets to formation of thinner rods. Being a polar basic aprotic solvent DMSO also is a major component in controlling the growth of $\mathrm{ZnO}$ structures obtained by electrodeposition. ${ }^{30,31}$ In these studies, DMSO was shown to be also inducing anisotropic growth. A mass of DMSO is most likely absorbed on to the polar plane, hence restrains the growth along (0001) plane. Hence, $\mathrm{ZnO}$ particles obtained in the absence of $\mathrm{Mn}$ (II) ions in DMSO- $\mathrm{H}_{2} \mathrm{O}$ mixture are in the form of platelets. DMSO also behaves as a reactant by increasing the $\mathrm{OH}^{-}$ion concentration according to the following equation: ${ }^{32}$

$$
\left(\mathrm{CH}_{3}\right)_{2} \mathrm{SO}+\mathrm{HOH} \rightarrow\left(\mathrm{CH}_{3}\right)_{2} \mathrm{SOH}^{+}+\mathrm{OH}^{-}
$$

Higher $\mathrm{OH}^{-}$concentration also accelerates the hydroxylation reaction (Eq. 3) as well as nucleation rate. However, Mn(II) addition stimulates formation of hexagonal rods. It is very important to note that although the mixture contains high amount of DMSO, the final product is the film composed of rods. Presence of $\mathrm{Mn}^{2+}$ in the mixture together with the reasons given above results in the formation of rod structures. It is most likely that the $\mathrm{Mn}$ (II) species in the deposition solution are adsorbed onto the nonpolar surfaces of $\mathrm{ZnO}$ parallel to the $c$ axis and hence preventing the growth in the lateral direction. Below $20 \mathrm{mM}$ $\mathrm{Mn}$ (II) ions are not sufficient to induce thinner rod formation (Figure 1b). As Mn(II) concentration increases above $20 \mathrm{mM}$, lateral growth is far more restricted hence diameter of hexagonal rods decreases as it is observed for $\mathrm{Cr}^{3+}$-doped $\mathrm{ZnO}$ particles before. ${ }^{33}$ Similar observation was also reported by Lincot et al. ${ }^{34,35}$ In their manuscripts related with $\mathrm{ZnO}$ deposition in the presence of lanthanide ions, they have reported that increase in the lanthanide concentration and formation of hydroxide layer resulted in lower rod density. Formation of Mn related species in between the rods during the deposition might be responsible for thinner rods in our films. We have not, however, found any evidence of hydroxide layer beneath the $\mathrm{ZnO}$ layers when we analyze the films with electron microscope and Energy Dispersive X-ray Fluorescence (EDX). On the other hand, SEM and EDX investigations revealed the presence of $\mathrm{Mn}$ containing precipitates on small areas, particularly at the edges, on some films (data not shown) and this could be the evidence for the growth of thinner $\mathrm{ZnO}$ rods on the surface as a result of the absorption of $\mathrm{Mn}$-species on lateral surface of $\mathrm{ZnO}$ structures.

The composition of the Mn-doped $\mathrm{ZnO}$ films and the chemical bonding states of the metals were examined by studying the $\mathrm{Zn} 2 \mathrm{p}$ and Mn $2 p$ core level XPS spectra. The peak positions were same for all of the films. Figure 4a displays Zn 2p XPS spectrum of the film prepared with lowest $[\mathrm{Mn}(\mathrm{II})] /[\mathrm{Zn}(\mathrm{II})]$ feed ratio. There appear two peaks centered around 1022.45 and 1045.38 which corresponds to $\mathrm{Zn} 2 \mathrm{p}_{3 / 2}$ and $2 \mathrm{p}_{1 / 2}$ respectively matching the binding energy of $\mathrm{Zn}^{2+}$ in $\mathrm{ZnO}$. The $\mathrm{Zn} 2 \mathrm{p}$ binding energies are very similar for all of the films. The position of the $\mathrm{Zn} 2 \mathrm{p}_{3 / 2}$ peak does not vary with etching time indicating good chemical stability of $\mathrm{Zn}$ through the film. Mn $2 p$ core level XPS spectrum of the same film is shown in Figure $4 b$. It can be seen that there are three peaks appearing at $641.62,652.91$ and $655.46 \mathrm{eV}$ which are obtained similarly for all other samples. The peak centered at 641.62 is at higher binding energy than $\mathrm{Mn}^{2+}$ $\left(2 \mathrm{p}_{3 / 2}\right)(\sim 641 \mathrm{eV})$ found in $\mathrm{Mn}$-doped $\mathrm{ZnO}$ samples earlier and at lower binding energy than the value which is commonly observed for $\mathrm{Mn}^{3+}\left(2 \mathrm{p}_{3 / 2}\right)(\sim 642 \mathrm{eV})$ in literature. ${ }^{11,21,16,20,36}$ Nesbitt and Banerjee proposed $640.8 \pm 0.3 \mathrm{eV}$ as the binding energy of $\mathrm{Mn}^{2+}\left(2 \mathrm{p}_{3 / 2}\right)$ after a detailed study and literature search on XPS spectra of $\mathrm{Mn}(2 \mathrm{p}) .{ }^{37}$ Plus, they determined that the position of the $\mathrm{Mn}^{3+}\left(2 \mathrm{p}_{3 / 2}\right)$ peak of oxides range between 641.7 and $641.9 \mathrm{eV}$. An earlier study on the transition metal oxide spectra assigns $641.7 \mathrm{eV}$ to the $2 \mathrm{p}_{3 / 2}$ peak to manganese $3+$ oxidation state both in $\mathrm{Mn}_{2} \mathrm{O}_{3}$ and mixed metal oxide $\mathrm{Mn}_{3} \mathrm{O}_{4} \cdot{ }^{38}$ In addition, the $11.29 \mathrm{eV}$ spin orbit splitting between the $\mathrm{Mn} 2 \mathrm{p}_{3 / 2}$ and $\mathrm{Mn} 2 \mathrm{p}_{1 / 2}$ is in agreement with previous reports on XPS spectrum of $\mathrm{Mn}_{3} \mathrm{O}_{4 .}{ }^{39,40}$ Hence, the peaks at 641.62 and 652.91 can be attributed to $2 p_{3 / 2}$ and $2 p_{1 / 2}$ orbitals in the mixed valence oxide. Furthermore, presence of $\mathrm{Zn}\left(\mathrm{L}_{2} \mathrm{M}_{23} \mathrm{M}_{23}\right)$ Auger transition (around $655 \mathrm{eV}$ ) besides confirming strong interaction between $\mathrm{Zn}$ and $\mathrm{Mn}$, also implies oxidation state higher than $2+$ for $\mathrm{Mn} .{ }^{41}$ Metallic manganese formation
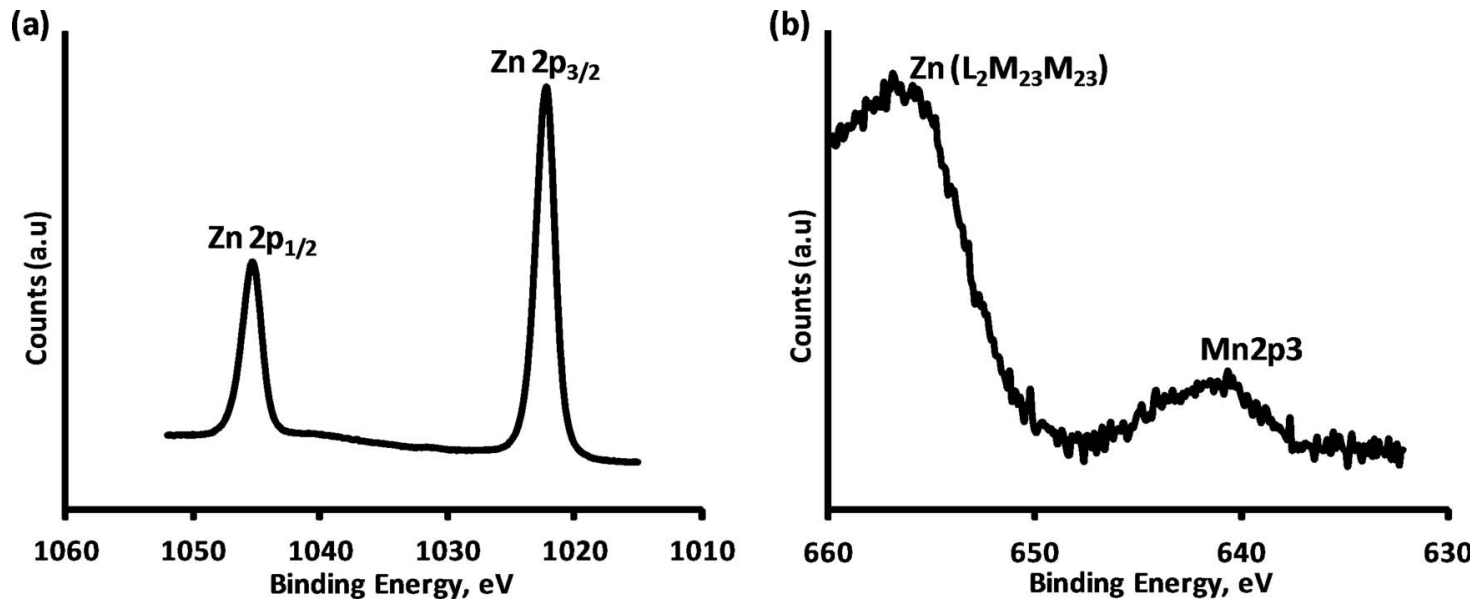

Figure 4. The XPS spectra of $\mathrm{Mn}-\mathrm{ZnO}$ film prepared by $[\mathrm{Mn}(\mathrm{II})] /[\mathrm{Zn}(\mathrm{II})]$ ratio of 0.2 a) $\mathrm{Zn} 2 \mathrm{p}$ scan b) Mn 2p scan. 


\section{Table I. The Mn content in the films obtained by different feed} ratios. (determined by XPS)

\begin{tabular}{cccc}
$\begin{array}{c}\text { Mn(II):Zn(II) } \\
\text { In the deposition bath }\end{array}$ & $\begin{array}{c}\text { Mn\% } \\
\text { In the film }\end{array}$ & $\begin{array}{c}\mathrm{Zn} \% \\
\text { In the film }\end{array}$ & $\begin{array}{c}\mathrm{Mn}(\mathrm{II}): \mathrm{Zn}(\mathrm{II}) \\
\text { In the film }\end{array}$ \\
\hline 0.2 & 3.3 & 96.7 & 0.03 \\
0.4 & 3.26 & 96.74 & 0.033 \\
0.6 & 2.88 & 97.12 & 0.029 \\
0.8 & 3.83 & 96.17 & 0.039 \\
1 & 3.64 & 96.34 & 0.037
\end{tabular}

was not observed $(637.7 \mathrm{eV}) .{ }^{19}$ According to the XPS results, the real manganese content in the films is around 3\% regardless of the $\mathrm{Mn}$ (II) concentration in the deposition solution (Table I).

Figure 5 shows the room-temperature photoluminescence (PL) spectra of the doped and undoped $\mathrm{ZnO}$ films prepared by the hydrothermal-electrodeposition. All the films show strong near-bandedge (NBE) emission around $375-385 \mathrm{~nm}$ due to the transitions of the excited electrons from conduction band to valence band but almost no visible emission. Emission in the visible region is generally attributed to the structural defects that might trap the photogenerated hole ${ }^{27}$ and the intensity of NBE emission relative to defect-related visible emission is a sign of crystal quality. ${ }^{42}$ Since, high intensity ratio implies high crystal quality, it can be concluded that doping $\mathrm{ZnO}$ with $\mathrm{Mn}$ (II) ions does not induce structural defects in the lattice which can be attributed to similar radii of the two cations as discussed above. On the other hand, UV emission is slightly shifted to lower wavelength region in the $\mathrm{Mn}$-doped $\mathrm{ZnO}$ films. This blueshift might be explained by Burstein-Moss effect which states that excessive carriers from the dopant manganese ions fill the conduction band and result in bandgap broadening. ${ }^{43,44}$ The fact that UV emission does not shift further with increasing $\mathrm{Mn}$ (II) concentration suggests the level of manganese that can be incorporated to $\mathrm{ZnO}$ is limited which is in line with XPS results.

\section{Conclusions}

Hydrothermal-electrodeposition at $130^{\circ} \mathrm{C}$ was successfully employed to produce $\mathrm{Mn}$-doped $\mathrm{ZnO}$ films. Hexagonal wurtzite $\mathrm{ZnO}$ structure growing toward (002) direction was obtained with no impu-

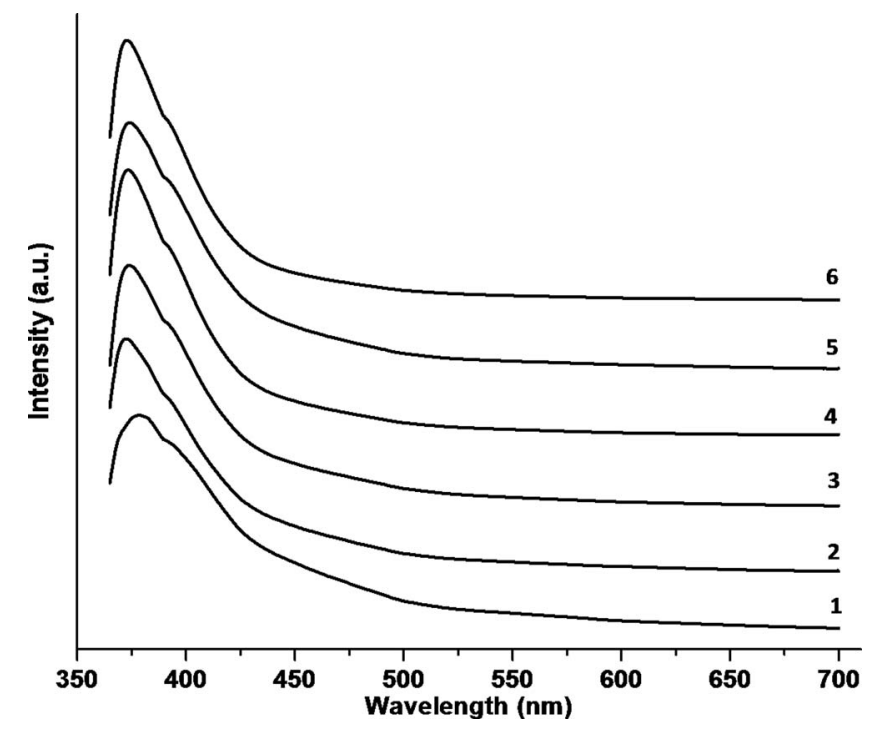

Figure 5. Photoluminescence spectra of undoped and Mn-doped $\mathrm{ZnO}$ films. Curve 1: only $\mathrm{Zn}\left(\mathrm{NO}_{3}\right)_{2}$, Curve 2: $[\mathrm{Mn}(\mathrm{II})] /[\mathrm{Zn}(\mathrm{II})]=0.2$, curve 3: $[\mathrm{Mn}(\mathrm{II})] /[\mathrm{Zn}(\mathrm{II})]=0.4$, curve $4:[\mathrm{Mn}(\mathrm{II})] /[\mathrm{Zn}(\mathrm{II})]=0.6$, curve 5 : $[\mathrm{Mn}(\mathrm{II})] /[\mathrm{Zn}(\mathrm{II})]=0.8$, curve $6:[\mathrm{Mn}(\mathrm{II})] /[\mathrm{Zn}(\mathrm{II})]=1$. rity phases. Obtained particles were of high crystal quality indicated by high intensity ratio of UV emission to visible emission. The lattice parameters are not altered on addition of Mn. Mn-doping affected the crystal growth enhancing formation of particles with high aspect ratio. As concentration of $\mathrm{Mn}$ (II) in the deposition bath increased, coalesced platelets were transformed into hexagonal particles of smaller diameter. XPS results display that Mn is present both in divalent and trivalent state in $\mathrm{ZnO}$ lattice. Presence of manganese induced a shift in UV emission toward lower wavelength by introducing excessive carriers into the lattice.

\section{Acknowledgments}

Authors thank to Koc University Faculty of Science for financial support. We also thank to Turkish Ministry of Development for the financial support provided for the establishment of Koc University Surface Science and Technology Center (KUYTAM).

\section{References}

1. D. C. Look, Mater. Sci. Eng. B, 80, 383 (2001)

2. U. Ozgur, Y. Alivov, C. Liu, C. Teke, M. Reshchikov, S. Dogăn, V. Avrutin, S. J. Cho, and H. Morkoc, J. Appl. Phys., 98, 041301 (2005).

3. S. M. Chou, L. G. Teoh, W. H. Lai, Y. H. Su, and M. H. Hon, Sensors, 6, 1420 (2006).

4. A. Ohtomoa, M. Kawasakia, Y. Sakuraib, Y. Yoshida, H. Koinumac, P. Yue, Z. K. Tange, G. K. L. Wonge, and Y. Segawaf, Mater. Sci. Eng. B, 54, 24 (1998).

5. J. H. Choy, E. S. Jang, J. H. Won, J. H. Chung, D. J. Jang, and Y. W. Kim, Adv. Mater., 15, 1911 (2003).

6. H. Kind, H. Yan, B. Messer, M. Law, and P. Yang, Adv. Mater., 14, 158 (2002).

7. M. Willander, O. Nur, N. Bano, and K. Sultana, New J. Phys., 11, 125020 (2009).

8. W. Y. Weng, S. J. Chang, C. L. Hsu, and T. J. Hsueh, ACS Appl. Mater. Interfaces, 3 , 162 (2011).

9. H. Majidi and J. B. Baxter, Electrochim. Acta, 56, 2703 (2010).

10. A. Ohtomo, M. Kawasaki, T. Koida, K. Masubuchi, H. Koinuma, Y. Sakurai, Y. Yoshida, T. Yasuda, and Y. Segawa, Appl. Phys. Lett., 72, 2466 (1998).

11. K. Wu, S. Gu, K. Tang, J. Ye, S. Zhu, M. Zhou, Y. Huang, M. Xu, R. Zhang, and Y. Zheng, J. Magn. Magn. Mater., 324, 1649 (2012).

12. T. Liu, H. Xu, W. S. Chin, P. Yang, Z. Yong, and A. T. S. Wee, J. Phys. Chem. $C$ 112, 13410 (2008)

13. K. Jug and V. Tikhomirov, J. Phys. Chem. A, 113, 11651 (2009).

14. T. Bu, M. Hilgendorff, S. Irsen, F. Wilhelm, A. Rogalev, D. Goll, and M. Giersig, J. Phys. Chem. C, 112, 2412 (2008).

15. Z. Yin, N. Chen, C. Chai, and F. Yang, J. Appl. Phys., 96, 5093 (2004).

16. S. Sain, J. Bhattacharjee, M. Mukherjee, D. Das, and S. K. Pradhan, J. Alloy Compd., 519, 112 (2012).

17. M. Tortosa, M. Mollar, and B. Marí, Phys. Status Solidi C, 5, 3467 (2008).

18. T. Fukumura, Z. Jin, A. Ohtomo, H. Koinuma, and M. Kawasaki, Appl. Phys. Lett., 75, 3366 (1999).

19. I. Polat, S. Aksu, M. Altunbas, S. Yılmaz, and E. Bacaksız, J. Solid State Chem., 184, 2683 (2011)

20. H. T. Cao, Z. L. Pei, J. Gong, C. Sun, R. F. Huang, and L. S. Wen, J. Solid State Chem., 177, 1480 (2004)

21. X. Yan, D. Hu, H. Li, L. Li, X. Chong, and Y. Wang, Physica B, 406, 3956 (2011).

22. Y. S. Wang, P. J. Thomas, and P. O'Brien, J. Phys. Chem. B, 110, 21412 (2006).

23. M. Tortosa, M. Mollar, and B. Mari, J. Cryst. Growth, 304, 97 (2007).

24. T. Yoshida, Thin Solid Films, 451-452, 166 (2004).

25. Z. L. Wang, J. Phys.: Condens. Matter, 16, R829 (2004)

26. T. Pauporte, R. Cortes, M. Froment, B. Beaumont, and D. Lincot, Chem. Mater., 14, 4702 (2002).

27. L. Xu, Y. Guo, Q. Liao, J. Zhang, and D. Xu, J. Phys. Chem. B, 109, 13519 (2005)

28. D. Pradhan and K. T. Leung, Langmuir, 24, 9707 (2008).

29. A. Goux, T. Pauporte, J. Chivot, and D. Lincot, Electrochim. Acta, 50, 2239 (2005).

30. X. Lu, D. Wang, G. Li, C. Su, D. Kuang, and Y. Tong, J. Phys. Chem. C, 2, 13574 (2009).

31. T. Zhai, S. Xie, Y. Zhao, X. Sun, X. Lu, M. Yu, M. Xu, F. Xiao, and Y. Tong, Cryst. Eng. Comm., 14, 1850 (2012).

32. G. Rodríguez-Gattorno, P. Santiago-Jacinto, L. Rendon-Vázquez, J. Németh, L. Dékány, and D. Díaz, J. Phys. Chem. B, 107, 12597 (2003).

33. C. J. Lan, J. S. Tsay, C. K. Lo, C. Lin, J. H. He, and R. J. Chung, J. Electrochem. Soc., 157, D559 (2010).

34. A. Goux, D. Lincot, and T. Pauporte, J. Electroanal. Chem., 587, 193 (2006).

35. A. Goux, D. Lincot, and T. Pauporte, Electrochim. Acta, 53, 50 (2007).

36. M. K. Sharma, R. N. Gayen, A. K. Pal, D. Kanjilal, and R. Chatterjee, Solid State Commun., 151, 1182 (2011).

37. D. Banerjee and H. W. Nesbitt, Am. Mineral., 83, 305 (1998).

38. C. N. R. Rao, D. D. Sarma, S. Vasudevan, and M. S. Hegde, Proc. R. Soc. A, 367, 239 (1979).

39. J. W. Lee, A. S. Hall, J. Kim, and T. E. Mallouk, Chem. Mater, 24, 1158 (2012) 
40. A. M. E. Raj, S. G. Victoria, V. B. Jothy, C. Ravidhas, J. Wollschlager, M. Suendorf, M. Nemann, M. Jayachandran, and C. Sanjeeviraja, Appl. Surf. Sci., 256, 2920 (2010).

41. S. Riyadi, A. Muafif, A. Nugroho, A. Rusydi, and M. O. Tjia, J. Phys.: Condens. Matter, 19, 476214 (2007).
42. C. Gu, J. Li, J. Lian, and G. Zheng, Appl. Surf. Sci., 253, 7011 (2007).

43. H. W. Lee, S. P. Lau, Y. G. Wang, K. Y. Tse, H. H. Hng, and B. K. Tay, J. Cryst. Growth, 268, 596 (2008)

44. Y. Lin, Y. Yang, J. Xu, X. Liu, J. Wang, Z. Huang, F. Zhang, and Y. Du, Chinese Phys. Lett., 24, 2685 (2007). 